\title{
4 \\ Linguistic demography of the Wik Region
}

\author{
Peter Sutton
}

In this chapter I focus on the number of clan estates per linguistic variety, beginning in the north of the region, and proceeding south. Further information about the same linguistic varieties may be found especially in Chapter 5.

The main reason for focusing on number of estates per variety is to arrive at estimates of dialect-owning populations in the proto-colonial period. This is on surer ground than an attempt to estimate numbers of speakers of those varieties. In the 1970 s, after a period of population loss, residential concentration and sedentisation, older people were still multilingual but often asymmetrically so. For example, while all owners of Wik-Me'enh also spoke Wik-Mungkan, most speakers of Wik-Mungkan did not speak Wik-Me'enh. Older Wik-Me'enh people also spoke Wik-Ngathan, but only some Wik-Ngathan people spoke Wik-Me'enh. This seems to have been a reflection of relative population numbers.

\section{Wik-Way}

The Wik-Way linguistic varieties are a geopolitically defined subset of the Northern Paman subgroup of Paman languages. The Wik-Way area is between the Archer River and the Weipa Peninsula to its north. There are other Northern Paman languages further north beyond Weipa to the tip 
of Cape York Peninsula, but they are not discussed here. Here I examine just the subset of Northern Paman speech varieties whose owners were part of the Wik native title claim.

Regarding the varieties listed here, and particularly considering their sharing of phonological developments and lexicon, Ken Hale (1966:163ff.) has presented evidence that they may be subgrouped as follows (some would say as five technically defined languages):

1. Alngith/ Linngithigh

2. Mamangathi/Thyanngayth/ Ndrrwa'ngayth/ Ndrra'ngith

3. Ngkoth /Trotj

4. Arraythinngith

5. Mbiywom.

However, the first two subgroups appear to belong to a dialect chain (Hale 1966:175) such that each shares at least 80 per cent of basic lexicon with at least one of the other varieties, but at the opposite extreme two of the chain's members, Thyanngayth and Linngithigh, share only 54 per cent.

Here I list language varieties under their self-name, but they also had a variety of other names in different languages. Arraythinngith, for example, was known as Arrithinngithigh in Linngithigh, and as Arrithinngayth in Ndrrwa'ngayth (Hale 1966:166), and I can add that it was also known as Arraythinngith, possibly in Ndrra'ngith, and as Arreythinwum, probably in Yinwum. It probably had several other names as well—one expects there to have been a Wik version something like *Wik-Arrithangathiy, for example, but it has not been recorded.

Given that Adithinngithigh and Arrithinngithigh seem to have been identified with only one estate each and the names are so similar, it might be tempting to consider their distinct spellings mere artefacts of the recording process, but the names are indeed distinct and moreover the relevant estates are non-contiguous and owned by different people (my own field work). Basically, McConnel's rough map (1939-40:55) seems to have been the first to get it right, showing 'Adetingiti' separate from 'Aritingiti' (in spite of demurrings by Sharp 1939:265fn.). Similarly, Ndrra' ngith and Ndrrangith estates are non-contiguously located and have distinct custodians. (The dialect names here differ only by the presence 
of the glottal stop I'/ in the first.) Separate again are Ndwa'ngith and Ndrrwa angathi, the countries connected with the latter two lying too far north to come within the purview of the mapping research referred to here. In short, unravelling the complexity of language variety nomenclature in the Wik-Way sub-region has had to rely heavily on accurately heard phonetic renderings of the names.

According to Ken Hale, Mamngayth (Mamangathi) is one of three virtually identical dialects subsumed under the title Awngthim (Hale 1966:165). According to Crowley, Mamangathi is referred to as one of several 'groups' speaking the Awngthim language, and the implication is that these were exogamous clan-groups rather than dialect groups per se (see Crowley 1981:150). The data I have suggest that the name Mamangathi (Mamngayth, Mamangithigh, etc. depending on the language in which it is being named) functioned as the name of a linguistic variety, and was not just a clan name. I am not aware of clans being formally named in the region.

Table 4.1: Wik-Way estates

\begin{tabular}{|l|c|}
\hline Named variety & No. of estates c. 1900 \\
\hline Adithinngithigh & 1 \\
\hline Alngith & 1 \\
\hline Anathangayth & 8 (+ two possibles) \\
\hline Andjingith & 1 \\
\hline Arraythinngith & 1 \\
\hline Latumngith & 4 \\
\hline Linngithigh & 1 \\
\hline Mamangathi & 2 \\
\hline Mbiywom & 1 \\
\hline Ndrra'ngith & 1 \\
\hline Ndrrangith & 41 \\
\hline Ngkoth & (+ two possibles) \\
\hline Paach (Wik Paach) & $\mathbf{3 1}$ (35) \\
\hline Total & (average 2.38 (2.69)) \\
\hline
\end{tabular}

1 Of these estates, two were also probably affiliated with Andjingith. They are also included under Andjingith above as 'possibles'. 


\section{Wik Subgroup}

Here I give clan estate figures for the varieties of the Wik Subgroup of the Middle Paman group of languages whose countries fell within the Wik native title case claim boundaries. I omit south-eastern Wik varieties Ayapathu and Pakanh(u) (also known as Aya-Pathu, Aya-Pakanh, etc.). They mainly fall outside the study area in this case. ${ }^{2}$ Very closely related to each other as dialects of a single technically defined language, they are also very similar to Wik-Iyanh and Wik-Mungkan but given their geographical coverage one expects local varieties to be more divergent the further apart they are. There are two estates affiliated to each of Ayapathu and Pakanh in our data from the hinterland of western Cape York Peninsula. There were in the past at least five more Ayapathu estates on and inland from the western shores of Princess Charlotte Bay on the east coast of the Peninsula. These have passed to the Mumpithamu clan (of the Uuku Umpithamu language, not a Wik variety) and in fact to the whole modern Lama Lama tribe.

\section{Coastal and pericoastal varieties of the Wik Subgroup}

In Chapter 5, I present a schematic listing of Wik Subgroup linguistic varieties classified into coastal, pericoastal and inland environments.

By 'coastal' speech, I generally mean varieties whose clan estates include areas somewhere between the sea and the flood plains that lie between the Holocene and Pleistocene dune systems of western Cape York Peninsula. The Holocene systems lie commonly just behind the beach. The Pleistocene dune systems lie commonly about 10-20 kilometres east of them, abutting, on their east, the vast messmate forests of the interior. The dune systems carry Indo-Malaysian dune thickets that are very rich in resources. Between the Archer and Edward rivers there is an abrupt transition from coastal environments to the great messmate forests of the inland in the region. Note also that the same forest environment runs right to the beach strip north of the Archer River in the Wik-Way area.

2 See Verstraete and Rigsby (2015:1-17) for details regarding these two varieties and their countries. I also acknowledge Ayapathu/Mumpithamu data from Bruce Rigsby, pers. comm., and Ayapathu/Pakanh data from Bruce Rigsby and Philip Hamilton, pers. comm. 
By 'pericoastal' dialects, I mean varieties whose clan estates include areas somewhere between the Holocene dune system and the dry sclerophyll forests that dominate the inland east of the Pleistocene system and have no frontage on the Gulf of Carpentaria coastline. This zone is neither true coast nor true inland: it includes tidal reaches and flood plains, but also dry sclerophyll forest. This two-way liminality is reflected culturally and politically in a number of ways. Linguistically, however, the pericoastal varieties leaned more strongly to the inland dialect types, and were predominantly called Wik-Mungkan in the north and Wik-Iyanh in the south.

By 'inland' varieties, I generally mean varieties whose clan estates include areas running east of the Pleistocene dune system up to the Great Dividing Range far to the east. This is country dominated by forests of Eucalyptus tetrodonta (Darwin stringybark, messmate) and other hardwoods, a far less rich environment than the coastal and pericoastal zones, and a zone with vastly larger clan estates and vastly lower linguistic diversity.

\section{Northern coastal}

Varieties here are arranged very roughly north to south, but they tend to occur in a patchwork arrangement not in single-variety blocs.

\section{Table 4.2: Northern coastal estates}

\begin{tabular}{|l|c|}
\hline Named variety & No. of estates c. $\mathbf{1 9 0 0}$ \\
\hline Wik-Alken/Wik-Elkenh ${ }^{3}$ & 5 \\
\hline Wik-Ngatharr & 3 \\
\hline Wik-Ngathan & \\
\hline Total & 7 \\
\hline
\end{tabular}

These three varieties are dialects of a single technical language, although Wik-Ngathan is clearly distinct from the others in a number of morphosyntactic and lexical ways and unlike the other varieties does not

3 Some say this is the same as Wik-Ngatharr and others say it is not, but, in any case, they are very similar or virtually identical varieties. Wik-Ngatharr appears to be originally the Wik-Mungkan name for the variety self-named Wik-Elkenh, but has become widely adopted.

4 One Wik-Ngathan variety was renamed Wik-Iincheyn in the late 1970s but has since reverted. This name is also said to occur further south but I have no precise details to hand (John von Sturmer, pers. comm.). 
engage in synchronic initial-dropping and certain other complexities that reduce the appearance of similarity that one gains from inspecting lexical cognates. 'Mutual intelligibility' is especially problematic here. Wik-Alken/Wik-Elkenh and Wik-Ngatharr are different names for what is as far as I know the same dialect.

Also on the coast are two Wik-Mungkan estates (12 and 20, Appendix 2), not contiguous with each other or with any other Wik-Mungkan estate, and thus surrounded by estates affiliated with other languages (in both the named sense and the technical sense). For the purposes of this table they are located further below with the other Wik-Mungkan estates, the great majority of which are in the inland. There was, however, no particular close interaction in the past between coastal and inland Wik-Mungkan people, the coastal people intermarrying and living with other coastal people and being multilingual, not showing any preference for spouses of the same language.

\section{Northern pericoastal}

Table 4.3: Northern pericoastal estates

\begin{tabular}{|l|c|}
\hline Named variety & No. of estates c. 1900 \\
\hline Wik-Ep/Wik-lit & 4 \\
\hline Wik-Me'enh & $4^{5}[+1$ possible] \\
\hline Wik-Keyenganh & 1 \\
\hline Total & $\begin{array}{c}\mathbf{9}(\mathbf{1 0}) \\
\text { (average 3.0 (3.3)) }\end{array}$ \\
\hline
\end{tabular}

These varieties of a single language form a north-south cluster of estates running along the pericoastal plains between just south of the Kirke River and just south of the Kendall River.

\section{Southern (coastal, pericoastal, inland)}

These varieties are dialects of a single (technical) language, the Kugu Nganhcarra described in the work of Smith and Johnson (e.g. 2000). I prefer the practical spelling Kugu Ngancharra. (It is known as

5 One estate's language was known as both Wik-Ep and Wik-Me'enh, unlike others north of it known as Wik-Ep and others south of it known as Wik-Me'enh. This dual naming may or may not reflect an empirically midway variety. 
Wik-Ngencherr in northern Wik Subgroup languages.) Of these Kugu Ngancharra varieties, Wik-Iyanh is closest to Wik-Mungkan and like most of the Wik-Mungkan countries it also belongs to the inland region. Lexically it reflects a sustained relationship with Wik-Mungkan but it is structurally closer to other Kugu Ngancharra languages (Smith and Johnson 2000). Varieties are here arranged roughly north to south, but apart from Wik-Iyanh they occur in something of a patchwork pattern, as also do those north of them along the coast.

Table 4.4: Southern estates

\begin{tabular}{|l|c|}
\hline Named variety & No. of estates c. $\mathbf{1 9 0 0}$ \\
\hline Wik-lyanh & 16 \\
\hline Wik-lyanyi ${ }^{7}$ & 1 \\
\hline Kug Ugbanh & 3 \\
\hline Kugu Muminh & 7 \\
\hline Kug Uwanh & 3 \\
\hline Kugu Mu'inh & 6 \\
\hline Kugu Y''anh & 1 \\
\hline Kugu Mangk & $2^{8}$ \\
\hline Total & $\mathbf{3 9}$ \\
\hline (Mostly) inland & (average 4.8) \\
\hline Wik-Mungkan & 8 [+ 1 possible] \\
\hline Wik-lyeyn ${ }^{10}$ & 2 \\
\hline Mungkanhu & 1 [some doubt] \\
\hline Total & $\mathbf{1 0}$ (12) \\
\hline
\end{tabular}

6 Under this term this I include the self-named dialect Wik-Iyanh Tharr-tharrn, known in Wik-Ngathan as Wik-Iyanh Yaarrk, a name translated into English as 'half Wik-Iyanh' (see Sutton 1978:183-84).

7 Here I tentatively include Wik-Iyanyi, a variety from the top of Kendall River and probably west of Coleman Creek, but am not sure that this is a self-name. It may be similar to, or an alternative name for, Pakanh.

8 Smith and Johnson (2000:358) consider Kugu Mangk likely to be an alternative name to Kugu Yi'anh, while some say they are distinct (von Sturmer 1978:171).

9 As stated above, two Wik-Mungkan estates that are coastal 'outliers' have been included here as their patrilects are demonstrably much the same as inland Wik-Mungkan, although there are differences. The identification of Wik-Iyeyn and Mungkanhu as varieties of the same language as Wik-Mungkan is tentative. They may belong with Wik-Iyanh in the Kugu Ngancharra set, as they fall south of the Wik-Mungkan estates proper, but data that would solve the question are not to hand. 10 Technically Wik-Iyeń. 
If we rearrange the data on estates per named variety so as to isolate the inland estates from the coastal and pericoastal we get the following:

Table 4.5: Coastal and pericoastal named varieties

\begin{tabular}{|l|c|}
\hline Named variety & No. of estates c. $\mathbf{1 9 0 0}$ \\
\hline Wik-Alken/Wik-Elkenh & 5 \\
\hline Wik-Ngatharr & 3 \\
\hline Wik-Ngathan & 7 \\
\hline Wik-Mungkan & 2 \\
\hline Wik-Ep/Wik-lit & 4 \\
\hline Wik-Me'enh & 4 [+ 1 possible] \\
\hline Wik-Keyenganh & 1 \\
\hline Kugu Mangk & 2 \\
\hline Kugu Muminh & 7 \\
\hline Kugu Mu'inh & 6 \\
\hline Kug Ugbanh & 3 \\
\hline Kug Uwanh & 3 \\
\hline Kugu Y'anh & 1 \\
\hline Total & $\mathbf{5 2}(+\mathbf{1})$ \\
\hline
\end{tabular}

Table 4.6: Inland named varieties

\begin{tabular}{|l|c|}
\hline Named variety & No. of estates c. $\mathbf{1 9 0 0}$ \\
\hline Wik-Mungkan & $8[+1$ possible] \\
\hline Wik-lyeyn & 2 \\
\hline Mungkanhu & 1 [some doubt] ${ }^{11}$ \\
\hline Wik-lyanyi & 1 \\
\hline Wik-lyanh & 16 \\
\hline Total & $\begin{array}{c}\mathbf{2 7} \text { (29) } \\
\text { (average 5.4 (5.8)) }\end{array}$ \\
\hline
\end{tabular}

11 The doubt in this case is whether Mungkanhu is another name for a variety more often known as e.g. Wik-Iyanh. For this reason I place Mungkanhu among the 'possibles' in the total here. 
However, if we rearrange the data so as to suppress dialect differences and treat each technically defined language as a single unit, but restrict the estate figures just to each of the inland/non-inland halves, ${ }^{12}$ we find the following:

\section{Table 4.7: Coastal and pericoastal technically defined Wik Subgroup languages}

\begin{tabular}{|l|c|}
\hline Named variety & No. of estates c. 1900 \\
\hline 1. (Ngathan, Ngatharr, Elkenh/Alken) & 15 \\
\hline 2. (Ep/lit, Me'enh, Keyenganh) & $9(10)$ \\
\hline 3. (Mungkan, Mungkanhu, lyeyn) & 2 \\
\hline 4. (Kugu Ngancharra varieties) & 22 \\
\hline Total & $\begin{array}{c}\mathbf{4 8} \text { (49) } \\
\text { (average 12.0 (12.25)) }\end{array}$ \\
\hline
\end{tabular}

If we exclude the two Wik-Mungkan coastal outliers, however-and the evidence ${ }^{13}$ suggests these probably derived from an inland or pericoastal clan by succession and fission at some point in the last two or three centuries-this latter average would rise to 15.3 (15.7).

Table 4.8: Inland technically defined languages

\begin{tabular}{|l|c|}
\hline Named variety & No. of estates c. 1900 \\
\hline 3. (Mungkan, Mungkanhu, lyeyn) & $10[+2$ possibles] \\
\hline 4. (Kugu Ngancharra varieties) & 17 \\
\hline Total & $\begin{array}{c}\mathbf{2 7}(\mathbf{2 9}) \\
\text { (average 13.5 (14.5)) }\end{array}$ \\
\hline
\end{tabular}

Thus, in terms of technically defined languages, the inland ones are not significantly larger in terms of reconstructible populations than are the coastal ones.

12 A broad inland/coastal division is probably the most profound of the classical lines of social cleavage within the Wik Region as in so many others. The people from pericoastal estates, although in many ways occupying an intermediate position between the sandbeach and the inland forests, can be appropriately combined with the sandbeach people at this level of a gross distinction between the inlanders and the rest.

13 Apart from a shared dialect, they shared six of a possible 12 totems for which the data may be compared, and all four totemic personal names (three male, one female) for which data may be compared. Their totem species are characteristic of pericoastal and inland country rather than of the ocean. 
Disregarding distribution and arranging the languages in order of numbers of estates, we arrive at the following:

Table 4.9: Technically defined languages

\begin{tabular}{|l|c|}
\hline Named variety & No. of estates c. $\mathbf{1 9 0 0}$ \\
\hline 4. (Kugu Ngancharra varieties) & 39 \\
\hline 1. (Ngathan, Ngatharr, Elkenh/Alken) & 15 \\
\hline 3. (Mungkan, Mungkanhu, lyeyn) & $10(12)$ \\
\hline 2. (Ep/lit, Me'enh, Keyenganh) & $9(10)$ \\
\hline Total & $\mathbf{7 3 ~ ( 7 6 ) ~}$ \\
\end{tabular}

\section{Reconstructing populations}

If we estimate that these Wik estates were held by groups averaging somewhere in the range of 15-25 clan members prior to the effects of European contact, the number of owners of a technically defined language would have averaged in the range $275-475$.

The average clan membership could conceivably have been higher, perhaps as much as 30 , but as can be seen below, my estimated maximum of 2,000 for the study area prior to colonial impacts divided by an estimated 80 clans gives an average figure of exactly 25 , a figure only calculated at the very end of all the others. Remarkably, this is also the 'magic number' for the average small land-owning 'horde' in Joseph Birdsell's scheme of things (see section below, this chapter, Language group size and the 'magic number' of 500).

In 1976, the average size of the 18 extant clans whose estates lay between the Love and Kendall rivers along the coast was 21 persons. The sample was 377 people (Sutton 1978:104). The average here is comparable with similar figures from other parts of north Australia (see Peterson and Long 1986:69) where Peterson's 11 non-Wik northern examples yield a patrilineal group average size of 22.7. If the extinct clans are rated as having zero members and added to the calculations, the Wik sample average of 1976 is lower (14.5), but still within the normal range for north Australia. The latter, on the basis of nine non-Wik northern nondesert examples (Peterson and Long 1986:69), ran from a depleted 11.1 
(Yir Yoront) to a somewhat exceptional 45.3 (Yolngu), all calculated by a more complex method than my own crude averages but with not very dissimilar results. If we also omit the somewhat distinctive Yolngu from that list, the average for eight northern samples drops to 19.8 with a range of 11.1-28.8.

However, the degree of Wik depopulation well prior to 1976 had been substantial and followed the introduction of exotic diseases to the region in the late nineteenth and early twentieth centuries. Clans with estates closest to river mouths seem often to have had fewer survivors than others. Just how far the Wik clans were along the road to population recovery by 1976 is unclear but I think they still had a way to go. In order to get a longer-term picture, I have estimated that in c. 1900 Wik patrilineal estate groups would on average fall within the range of 15-25 persons. Individually, they would have ranged between none and probably a few dozen.

The range of reconstructible populations owning each technically defined language as at about the year 1900, using the 15-25 persons range and multiplying it by the number of estates per language, is as follows:

Table 4.10: Reconstructed number of estates per language

\begin{tabular}{|l|c|}
\hline 4. (Kugu Ngancharra varieties) & $585-975$ \\
\hline 1. (Ngathan, Ngatharr, Elkenh/Alken) & $225-375$ \\
\hline 3. (Mungkan, Mungkanhu, lyeyn) & $150-300$ \\
\hline 2. (Ep/lit, Me'enh, Keyenganh) & $135-250$ \\
\hline Totals & $\mathbf{1 , 0 9 5 - 1 , 9 0 0}$ \\
\hline
\end{tabular}

Assuming we have missed at least some estates in our research, it would be safe to say there were at least 80 estates associated with languages of the Wik Subgroup between the Archer and Edward rivers and inland to about Rokeby and the upper Edward River in c. 1900. On the same clan-size assumptions made immediately above, the immediate pre-European population of the area would thus have been roughly of the order of 1,200-2,000 people.

Ursula McConnel's rough estimates of those living in 1929, based on far less specific data, are as follows: 
Table 4.11: McConnel's estimates of those living in 1929

\begin{tabular}{|l|c|}
\hline Archer River Wik-Mungkan & $50-100$ \\
\hline Holroyd, Kendall, Edward rivers & 200 approximately \\
\hline Coastal [Wik] tribes & $200-300$ \\
\hline Totals & $\mathbf{4 5 0 - 6 0 0}$ \\
\hline
\end{tabular}

Source: McConnel (1930a:99)

She added: 'According to report the population was once [i.e. before the development of coastal trade] three or four times as great' (McConnel 1930a:99).

Most of the Wik peoples were coming into regular contact with missionaries at the same time as immunisations and other kinds of modern practice were becoming standard, from the 1920s onwards. In their case, a large number of these immunisations were recorded by date and individual's name on the back of personal data cards kept by the mission staff. Apart from some of the earlier-contacted groups, which appear to have lost most or all of their members in several cases, the Wik Region generally is unlikely to have lost over 90 per cent of its people within the first 60 years in the way the Lake Eyre region did (Tindale 1941:73). On both McConnel's figures and mine (see above), at most the loss of Wik population is likely to have been about 75 per cent, to when it reached its lowest point, probably less than a decade before McConnel's first visit in 1927. From a population estimated above to have been of the order of 465-875, the Wik-Way from between the Archer and the Embley seem to have declined much more significantly, to perhaps even less than 10 per cent of their original numbers, although the details have not been worked out as yet.

McConnel's pre-European Wik population estimates may be summarised as:

Table 4.12: Summary of McConnel's pre-European Wik population estimates

\begin{tabular}{|l|c|c|}
\hline & lower estimate & upper estimate \\
\hline In 1929 & 450 & 600 \\
\hline Before: if 3 times as many & 135 & 1,800 \\
\hline Before: if 4 times as many & 1,800 & 2,400 \\
\hline
\end{tabular}


Shortly afterwards, however, McConnel wrote:

The Wik-munkan tribe ${ }^{14}$ is composed of approximately thirty such local clans, of which a few are practically extinct, the majority have from one to five members, a few from five to ten members, whilst others ... have from ten to twenty members ... one clan has at least forty or fifty members. As all these clans were probably at one time equally large, it may be assumed that the Wik-munkan tribe must have originally numbered from fifteen hundred to two thousand people (McConnel 1930a:181).

This method of reconstructing populations by extrapolating backwards from surviving knowledge of clan estates was probably that of McConnel's supervisor, A.R. Radcliffe-Brown. In the same year he published his 'Former numbers and distribution of the Australian Aborigines' (RadcliffeBrown 1930), which made the point that 'Any accurate estimate of the numbers of aborigines in any district requires a knowledge of the extent (i.e., area occupied) and the volume (i.e., number of persons) of the horde and the number of hordes in the tribe' (Radcliffe-Brown 1930:688; in this context his 'hordes' = my 'clans'). For the area now known as the Pilbara (Western Australia), he concluded from his own field work that 'the normal or average horde in former times [in the region] cannot have numbered less than 30 persons, men, women and children' (1930:688). He came to a similar conclusion using his own work in northern NSW (1930:694).

I regard McConnel's reconstructed figures here as being somewhat unreliable, given that the number of clans or local groups affiliated with Wik-Mungkan has been inflated by the incorporation into McConnel's listing of many non-Wik-Mungkan estates, including those whose language is actually Wik-Iyanh and some that are, for example, Mbiywom (exogenously 'Wik-Ompom'). While Wik-Iyanh is closely related to WikMungkan, Mbiywom is Northern Paman and Wik-Mungkan is Middle Paman and the two are thus only distantly related and are mutually unintelligible.

These include, for example, McConnel's Wik-Mungkan local groups I and VI, which in the 1970s were still remembered as having been Mbiywom but had transitioned to Wik-Mungkan. Her XI(a) had been Andjingith but was in transition to Wik-Mungkan in the 1970s. Her Wik-Mungkan

14 McConnel here used 'Wik-munkan' as a cover term for all the Wik tribes. 
groups XIII(c), XIV(a), XVII, XVIII, XXI were recorded in the 1970s as still having the language identity of Wik-liyanh. Her Wik-Mungkan group XXIV was Wik-Iiyanh and Pakanh. Her XVI we recorded as Wik-Iiyanh (formerly?) and Wik-Mungkanh. Her group XIII(d) is very possibly the Wik-Iyanh Clan 113 in Appendix 1. Her XI(b) is Clan 2, identified in the 1970s as Andjingith, Wik-Mungkan, and Wik Paach, but transitioning to Wik-Mungkan-only. It seems that McConnel was adopting the term 'Wik-Mungkan' as a cover term for many of the Wik Subgroup inland peoples, and people with Northern Paman languages who were undergoing language identity shift to the lingua franca WikMungkan, even if their own variety was not Wik-Mungkan in classical times. It may have been the case that McConnel's Wik-I(i)yanh informants tended to identify as Wik-Mungkan in the Aurukun Mission context, thus giving rise to her broad usage of the term.

McConnel (1930a:204-5) tabulated 25 'local groups of the Wik-Munkan tribe' between the Archer and Edward rivers, with surviving population estimates for 1929, but this yields a total population estimate of only 132-167 and it seems to omit a large number of Wik estates, especially coastal ones. On the basis of detailed accounts of estates in Sutton et al. (1990), northern Wik Subgroup estates numbered 43, southern Wik Subgroup estates numbered 53, yielding a total of 96. The rest of the Wik native title claim area-the Wik Way and Watson River areas north of Archer River - totalled 26 estates. The all-up total for the present study area is 122 clan estates.

McConnel shows only one extinct clan, which is most surprising. Even if possible sub-clans (e.g. McConnel's IX(a), IX(b), etc.) are separated out, the maximum number of deducible estates in her Wik-Mungkan list only rises to 36 .

Second, 30 clans in a population of 2,000 would yield an average reconstructed figure of 67 people per clan, which is way above the approximate average sizes for the north Australian literature. In the absence of any specialised regional social organisational complexity of 
the kind that may account for the figure of 55 per clan for the Yolngu in $1976,{ }^{15}$ it is extremely unlikely the pre-European Wik would have reached an average clan size of anything like 67 .

An estimate of 1,200-2,000 people affiliated to varieties of four technically defined languages (see Chapter 5), using fine-grained mapping data, clearly matches quite well with McConnel's estimated total for the same region based on a rather different method. The fine-grained method also yields a range of estimated owner populations per language (as technically defined) of 135-975, which is an enormous span and one that shows how the use of a rule of thumb of ' 500 people per language' can be quite remote from the local facts. If instead we examine the reconstructible population ranges for proper-named linguistic varieties in the Wik case, it extends from a low of 15-25 (e.g. Wik-Keyenganh with one estate) to 240-400 (Wik-Iyanh with 16 estates). Most of the 18 named Wik varieties considered here fall well below these latter figures, in fact 16 of them fall below Wik-Mungkan which had eight or nine estates (120-225 people). ${ }^{16}$

Turning again to the northern area between the Archer and the Embley, an estimate based on 15-25 people per clan multiplied by 31-35 clans comes to a rough population estimate of $465-875$ people. Given there are 13 named language varieties in this case, that comes to about 35-60 persons per named variety. Even if we were to assume an average of 35 persons for each of 35 clans, that would still result in an average of only 94 persons per named variety in this area. These were very tiny linguistic country units.

In terms of technically defined languages (i.e. sets of mutually intelligible dialects), I am unable to conclude exactly how many there were in this small area, but a figure of six or more seems not unreasonable, given the comparative data already published by Ken Hale. ${ }^{17}$ At a figure of six such 'technical' languages the estimate of how many people there were on average per language comes to a range of 77.5 to 145.8 using $15-25$ as the

15 The range is cited by Keen (1978:21) as 4-230, so his approximate average figure of 55 is an average for extant clans only. Adding those with zero persons to the calculations, the average comes down to $48.63(1070 \div 22)$. In 1928-29, W.L. Warner, who worked in a similar part of the region, found Yolngu clans averaged 40 or 50 individuals (1937:16).

16 Even if pre-colonial clans averaged 35 members instead, this figure would rise only to 280-315. All of which leads to the fascinating question as to why it is that Wik-Mungkan has become not only the Indigenous lingua franca of Aurukun and parts of its wider region, but has also predominantly replaced a large number of other varieties formerly spoken in the region.

17 Especially Hale (1966:163-76). 
clan average. Assuming 35 as the clan average, the average reconstructible population for each technically defined language would still be only 204 persons. In world terms these are stupendously small numbers. ${ }^{18}$

\section{Language group size and the 'magic number' of 500}

These are extremely modest figures, and fall well below the rule of thumb figure of about 500 people per Australian 'tribe' that has at times been used.

For example, R.M.W. Dixon's major textbook on Australian languages said 'There were around 600 distinct tribes in Australia ... It is thought that each tribe had something of the order of 500 members on average' (1980:18). This latter figure, which was not repeated in Dixon (2002), may derive from the work of Joseph Birdsell ${ }^{19}$ or perhaps from that of A.P. Elkin (see below, this section).

However, as Birdsell himself pointed out, Krzywicki (1934) had derived a mean value of Australian tribal populations 'as approximating 500 persons on the basis of data collected from the literature' (Birdsell 1973:339). Even earlier, A.R. Radcliffe-Brown (1930:693) had used the figure of 500 in order to make tribal estimates in at least one case. While reconstructing Victorian populations he said, 'If we allow only 500 persons for a tribe or language and only 100 to 120 for a dialect' (1930:693), thus prefiguring Birdsell's 'magic number' of 500 by over 20 years.

The source for Elkin's figures is not clear. In his general introductory work on Aborigines he said that 'the membership of a tribe varied from about 100 to 1,500 , and averaged about 500 or 600 ' (1938:10).$^{20}$ In turn, R.M. and C.H. Berndt, in their own introductory work, cited Elkin's figures without dissent, although they added that 'Tindale speaks of 500 as the average, but adds that this may be too high' (1988:33-4). Tindale's considered view was that the mean was about 450 (1974:110).

18 I offer analysis and continent-wide data on the subject of Australian language group sizes in Sutton (2019).

19 e.g. Birdsell (1953; 1957:53; 1958:196; 1968:230; 1973:339; 1979:136; 1987:10, 1993:34).

20 See also Elkin's pers. comm. to Radcliffe-Brown (1930:689). 
The figure of 500 persists in works such as the archaeological text by Harry Lourandos, who cites Birdsell as authority for stating that 'tribes' 'tended to average ... around five hundred' (1997:15). There Lourandos notes, however, that L.R. Hiatt questioned the 'magic number' estimates of Birdsell, who had stated that 'the size of the dialectical [sic: dialectal] tribe statistically tended toward a constant value which was estimated as approaching 500 persons' (Birdsell 1968:230). Hiatt (1968:245) responded that Elkin's estimated tribal size range was

about 100 to 1,500 or 2,000 . I recorded numbers in nine tribes near the Liverpool River of Arnhem Land. The largest of these ... is about 300. There was a good deal of intermarriage, particularly around the edges of this largest tribe.

Birdsell demurred at times from Norman Tindale's conclusion that precontact Aboriginal dialectal tribes approximated ' 400 to 600 persons with a mean of around 450' (1974:8). Birdsell considered the 'magic number' of 500 people per tribe to be a statistical abstraction that was approximated when such groups reached a relatively constant size under conditions of equilibrium, but the empirical data

in fact represents [sic] a fairly wide range of values, and indicate that serious disturbances of the balanced condition may not be compensated for until tribal population actually falls below 200 individuals or exceeds 800 individuals. (Birdsell 1958:196)

Birdsell's technique for estimating contact-period tribal sizes was primarily based on a single case of population decline published by Tindale (1941:73). ${ }^{21}$ On this basis, Birdsell made the working assumption that all Aboriginal populations declined by 50 per cent every 25 years after contact, thus suppressing the variation between misfortunes experienced by groups in different regions. He also made no allowance for the resurgence of populations after they reached their lowest point, which for many groups appears to have been around the time of the Spanish influenza pandemic of 1919. To reconstruct a tribal population, one made an estimate of living numbers and added to it 50 per cent for each period of 25 years since contact. Applying this doubtful method to 18 Western Australian tribes 'examined' in 1952-54, and adding five

21 The case was the Lake Eyre District. 
further reconstructions drawn from the work of others, Birdsell presented a list of 23 reconstructed tribal sizes for the western half of the continent (1993:33-4).

From this list Birdsell (1993:10) concluded that

the tribes are larger than average for the continent. Of the 23 tribes, only six fell into the normal range of 400-599 ... The pattern in ecological space was not consistent, for desert tribes included both very large ones and very small ones.

The list defined each reconstructed tribe as 'Large', 'Medium' or 'Small', and the ranges involved are as follows:

Table 4.13: Birdsell's estimate of tribal populations for 23 western cases

\begin{tabular}{|l|c|c|}
\hline Size & Number & Range \\
\hline Large & 9 & $750-1976$ \\
\hline Medium & 8 & $448-618$ \\
\hline Small & 6 & $192-324$ \\
\hline Total & $\mathbf{2 3}$ & Average 648 \\
\hline
\end{tabular}

Source: Birdsell (1993:33) (Note that the smallest figure is elsewhere (p. 34) given as 142.)

Not only did just six of these tribes fall into what Birdsell regarded as the 'normal' range of 400-599, but even on internal grounds this set, which ranges from the Kimberley coast in Western Australia south-east to the Mann Ranges in South Australia and east to the Tanami Desert (Northern Territory), contained almost twice as many non-medium cases as medium ones. In what sense then is an average of 648 a productive figure here? And in what sense is 500 an 'optimum figure' (Birdsell 1973:348) or a 'normal optimum size' (p. 349) for a pre-contact Aboriginal linguistic group when there are so many that may be reconstructed as having been well above or below it numerically?

Unfortunately, Birdsell's figures are based on named linguistic groupings only, and do not take into account the degrees of similarity and difference between their speech varieties. He generally makes an assumption that having a distinctly named language variety implies a high degree of social closure from those with other varieties, an assumption that cannot be generally sustained, whether or not neighbouring varieties were highly similar or profoundly different. Linguistic exogamy was variable but commonly substantial. ${ }^{22}$

22 For hard data see e.g. Sutton (1978:107-12; 2013a; 2013b). 


\section{Linguistic groups large and small}

Birdsell did attempt to deal with cases such as the reconstructed populations for Kamilaroi ${ }^{23}(6,000-7,000)$, Wongaibon (some thousands), Wiradjuri $(3,000)$ and Barkendji $(3,000)$, all from western New South Wales, and concluded that 'this deviant pattern' was not ecologically driven but probably resulted from the absence of strict patrilineality in assigning territorial interests. The emphasis of such groups on bilaterally derived rights and interests would have extended social networks beyond those of individuals in more strictly patrilineal tribes. He made no suggestion, however, that these exceptions were merely recorded midway through a particular phase of waxing and waning about an optimum figure of 500 persons in each case. Presumably this might have entailed a further hypothesis of an oscillation between patrilineality and bilaterality in reckoning the descent of land rights in western New South Wales, which would be even less likely.

On the other hand, Birdsell was prepared to refer to regions of small tribes as 'areas of apparent tribal fragmentation'. These 'primarily centred around the Boulia region in Queensland, the Daly River area on the western coast of Arnhem Land, and the so-called Murngin area of northeast Arnhem Land' (Birdsell 1973:341). His main hypothesis for explaining these exceptions was some form of fragmentation that occurred in the wake of the spread of initiatory rituals involving circumcision and subincision respectively (Birdsell 1973:341-6). The fact that the Daly River area had no such rituals in the relevant period was not addressed. In any case, there are so many 'exceptions' now demonstrable, including the many 'small tribes' of Cape York Peninsula-another region where there is no record of circumcision or subincision ever having been practised - that this argument is quite unconvincing as an Australia-wide generalisation.

Norman Tindale, in a chapter entitled 'Tribes large and small', attempted to explain why some tribes such as the Wiradjuri, Kamilaroi, Warlpiri, and Wadjari numbered in the low thousands, many others numbered 450 to 500, and yet others were significantly smaller (1974:110-17). His approach here was to fall back on economic determinism. The large tribes, he argued, tended to depend on grain-harvesting for their subsistence, while the smaller ones were relatively sedentary groups using rich and reliable

23 I retain the author's spelling of language names in this context. 
food environments, mainly coastal and estuarine environments intensively exploited for marine resources, or rainforest areas where the canopy yielded a constant food supply and rainfall was almost year-long. Like Birdsell, he also cited the Daly River as an exceptional example of 'small tribes of sedentary type', although in that case many were not on the coast per se but exploited wetlands areas nearby (1974:113). The others, one might conclude, were the non-coastal, non-rainforest, non-wetland, non-graindependent language groups with sizes frequently approximating 450-600 people. No such pattern is clearly evident from the data (Sutton 2020).

Among several examples of 'small tribes', Tindale cited the Wik area and what in this book has been referred to as that part of the Wik-Way area immediately to its north (1974:112-13). The smaller the area covered by a language variety name, the more Tindale seems to have been inclined to regard it as a 'sub-tribe', more or less on principle. In his catalogue of tribes he listed the Wik Subgroup language names as separate tribes, but from the Archer River to just north of the Embley he listed the names of 12 language varieties as 'hordes or incipient small tribes' under the 'valid embracing name' of 'Winduwinda' (Winda-Winda) (1974:188-90; see Map 3.5 above). It seems likely that the origin of the term WindaWinda is essentially geographical, centred on the 'Winda Winda Creek' area and covering groups with lands between the Archer and Mission rivers. ${ }^{24}$ But there are 'valid embracing names' for many congeries of language groups and Tindale's preference for entering the Wik-Way languages under Winduwinda seems unmotivated, except perhaps as a means of dealing with exceptional regions that fell outside his figures for average tribal sizes. In any case, he decided not to be too dogmatic about this particular arrangement: 'Those who feel inclined to regard the Winduwinda and Jupangati [Mapoon area] assemblages as having full tribal status may add a further dozen or more to the number of Australian tribes, bringing the total to over 600 tribes' (Tindale 1974:113). Writing about his field work on the same area, Lauriston Sharp said: 'Again in this area of small tribes it is not easy to distinguish local groupings, clans, or slightly differentiated linguistic groupings from tribes' (Sharp 1939:264; see Map 3.2 above).

24 See also W.E. Roth (1910:96 \& Pl.XXXI, more detail in the MS version 1900:2-4), McConnel (1939-40:62), and Hale (1966:176), on Winduwinda/Windawinda (Winda-Winda). The term has become archaic. 


\section{Patterns of diversity in the wider Wik Region}

Especially in the coastal and pericoastal areas, it is clear that in the wider Wik and Wik-Way region linguistic diversity was both real at a technical level and also highly valued and marked culturally. Even near-identical dialects could have distinct autochthonous names.

Just over half the 13 named Wik-Way varieties for which reasonably good mapping is available are intrinsically associated with just one estate each. This is within an area approximately 100 kilometres north-south by 75 kilometres east-west. In the past this concentrated Babel represented a challenging prospect for any newcomer, in spite of the regional tradition of highly skilled multilingualism. Although there were some marriages between Wik-Way and northern Wik Subgroup people prior to the effects of colonisation, a reason given to me for the difficulty of arranging such marriages was that Wik Subgroup people from south of the Archer were daunted by the difficulty of the languages to their north. Certainly the Wik-Way languages are phonologically much more complex than Wik Subgroup ones, but their sheer number and diversity would also have been a problem for those not brought up there, given the necessity to be a polyglot in order to survive socially, and to treat one's kin with respect, in this part of the world.

In the nineteenth and twentieth centuries, and probably earlier for one or two cases, language shift from Wik-Way-type languages to Wik Subgroup languages was occurring between the Archer and Kirke rivers. These events took place at the clan estate level, as can be seen in the detailed data in Appendix 1. This description is to be preferred to 'tribal expansion' given that population replacement by linguistic groups as a whole was not the norm.

This cultural transformation moved northwards along the coast and westwards towards the coast. It was probably accelerated by the impact of colonisation, as the Wik-Way lost much population and owners of Wik Subgroup varieties moved in to Aurukun on the north side of the Archer from the south, thus being better able to pursue succession to depopulated estates near the Archer and Love rivers to which they had connections. The emergent mission culture of Aurukun, after an initial period in which 
Wik-Way languages held sway, ${ }^{25}$ developed Wik-Mungkan as the town lingua franca and as the first language of most children regardless of their families' linguistic backgrounds.

The owners of the farthest inland Wik Subgroup varieties seem to have interacted closely with central peninsula people such as Kaantju. That is, genetic linguistic relationships here as in so many cases are not always aligned with social relationships. At the southern end of the Wik Region, where the Kugu Ngancharra varieties met Kuuk Thaayorre, social closure for the Wik was at its greatest (John von Sturmer, pers. comm.). Thaayorre is middlingly related to the Wik varieties but is not of the same subgroup, and at least superficially resembles Wik languages more than Wik-Way ones do-yet it seems there were more marriages between Wik and Wik-Way than between Wik and Thaayorre in the early twentieth century, even though there were not a great many. This relatively light social integration with coastal neighbours until several decades ago is possibly a reflection of the general northward and westward thrust of estate succession and ensuing linguistic and other cultural expansion by the Wik Subgroup people in protohistoric times. There may, however, be other explanations. ${ }^{26}$

The area just south of the lower Archer River represented a break-point between two regional Sprachbünde, one (Wik-Way) demanding greater multilingual competence than the other. To return to the figures above, linguistic diversity in the region is not so great in the inland as on the coast, an exception possibly being the Wik-Way area north of Archer River in which there is really not the same coast/hinterland distinction as obtains in a quite profound way south of Archer River. The geomorphology north of the Archer is clearly very different. North of the Archer to the Embley there is no pericoastal flood plain, and no Holocene and Pleistocene dune systems and sclerophyll forests extend virtually to the beach in most areas. The flood plains and Pleistocene dune systems south of Archer River hosted a great concentration of people, and thus also of estates. For this Wik Subgroup region (Archer-Edward rivers), proportionately more inland estates than coastal estates are identified with fewer proper-

25 In 1910, at the opening of the Aurukun church on 22 September, 'Mamus held the morning service in the Winda-Winda (Weipa language) which is understood by most northerners in Aurukun' (Richter 1910). Aurukun began in 1904.

26 The dynamics of classical period regionalism within Cape York Peninsula are as yet little explored, but there is enough data on which to develop models. 
named linguistic varieties, most notably in the cases of Wik-Iyanh and Wik-Mungkan. Furthermore, the historical-linguistic genetic diversity of the coastal Wik varieties is far greater than that of the inland. ${ }^{27}$

Thus, from both a nomenclature perspective as well as a technical comparative one, this means the inland Wik Region is comparatively uniform linguistically, being dominated by the closely related varieties Wik-Mungkan and Wik-Iyanh. A comparison of basic lexicons (Sutton 1978:178) showed Wik-Mungkan sharing 75 per cent with Wik-Iyanh and 77 per cent with Kugu Mu'inh, which would usually suggest reasonable mutual intelligibility, but in terms of phonological developments, morphology and morphophonology Wik-Iyanh belongs more with the Kugu Ngancharra subgroup than the one to which Wik-Mungkan belongs (Smith and Johnson 2000:364). Furthermore, while coastal varieties can be non-contiguously distributed in terms of their estates, both at the level of vernacular proper-named varieties and even that of technically defined languages ${ }^{28}$ the inland ones appear thus far to be the opposite and we have no evidence that they occur other than in single geographical blocs.

If we ignore the way the people themselves assign different names to varieties and look just at technical similarities and differences, the inland Wik varieties constitute only two (technical) languages divided among about 30 estates, while the coastal and pericoastal varieties constitute five technically defined languages divided among over 40 estates. The most genetically distant varieties of the Wik Subgroup, Wik-Ngathan/WikNgatharr/Wik-Elkenh, do not have estates in the inland.

These observations are consonant with the general tendency for the cultural life of the coastal people, and not merely their demographic distribution, to show greater intensity and diversity than that of inlanders. For example, while the coastal Wik groups surveyed here fall into four sub-regionally distinct ritual groups, known in Aurukun English as 'clans' or 'tribes', inlanders from between the Archer and Kendall rivers all share a single ritual identity across an area that greatly exceeds that of the coastal and pericoastal groups combined. Ceremonial diversity, along with linguistic diversity, is thus proportionately much lower in the inland than it is on the coast.

27 See Hale, this volume, Chapters 6 and 7, and Sutton (1991:60, 63).

28 See e.g. the map in Sutton (1991:65) and maps A2.1-A2.13 below. 
This text is taken from Linguistic Organisation and Native Title: The Wik Case, Australia, by Peter Sutton and Ken Hale, published 2021 by ANU Press, The Australian National University, Canberra, Australia.

doi.org/10.22459/LONT.2021.04 